\title{
Papillary thyroid microcarcinoma with lung metastases: a case report and review of the literature
}

Tadafumi Shimizu1, Takaaki Oba', Tatsunori Chino' , Ai Soma', Mayu Ono', Tokiko Ito ${ }^{1}$, Toshiharu Kanai ${ }^{1}$, Kazuma Maeno ${ }^{1}$, Yoshinori Sato ${ }^{2}$, Takeshi Uehara ${ }^{2}$ and Ken-ichi Ito ${ }^{1 *}$ (D)

\begin{abstract}
Background: Distant metastasis from papillary thyroid microcarcinoma (PTMC) is rare. Here we report a case of PTMC with multiple lung metastases.

Case presentation: A 64-year-old man presented to our hospital with abdominal pain. Computed tomography incidentally revealed multiple lung nodules. The lung tumor was histologically diagnosed as metastasis of papillary thyroid carcinoma (PTC) by core needle biopsy via thoracoscopy. The patient was referred to our department for further examination. Neck ultrasonography revealed a $0.9 \mathrm{~cm}$ hypoechoic nodule in the right lobe of the thyroid gland, which was diagnosed as PTC by fine-needle aspiration cytology. Subsequently, total thyroidectomy was performed, followed by radioiodine therapy. lodine-131 (131-I) scintigraphy showed a strong accumulation in the lung metastasis. The patient presented no evidence of progression of lung metastasis for 25 months after the operation.

Conclusions: Lymph node metastasis or extraglandular extension has been reported in the few published cases of metastatic PTMC, including the present case, and the average age of these cases was $58.8 \pm 12.0$ years. Although active surveillance without surgical resection is expected to become a standard of care for PTMC, this case indicates that a subset of PTMC patients with risk factors may develop distant metastases. Hence, careful preoperative screening is required to avoid complications associated with completion thyroidectomy.
\end{abstract}

Keywords: Papillary thyroid microcarcinoma, Lung metastasis, Lymph node metastasis, 131-iodine therapy

\section{Background}

A papillary thyroid carcinoma (PTC) measuring less than or equal to $1.0 \mathrm{~cm}$ in diameter is defined as a papillary thyroid microcarcinoma (PTMC). PTC generally grows slowly, and recent clinical studies have demonstrated that most PTMCs also do not increase in size for long time-periods [1-4]. Given the indolent nature of

\footnotetext{
* Correspondence: kenito@shinshu-u.ac.jp

'Division of Breast and Endocrine Surgery, Department of Surgery, Shinshu University School of Medicine, 3-1-1 Asahi, Matsumoto, Nagano 390-8621, Japan

Full list of author information is available at the end of the article
}

PTC, distant metastasis from PTMC has been considered very rare [3-5].

Although tumor size, multifocal cancers, extrathyroidal extension, and lymph node metastasis have been suggested as prognostic factors for PTMC recurrence [6-9], the risk factors for distant metastasis remain unclear. Here, we have reported a case of PTMC with multiple lung metastases and have reviewed similar cases in the literature to explore the risk factors for distant metastases from PTMC.

(c) The Author(s). 2021 Open Access This article is licensed under a Creative Commons Attribution 4.0 International License, which permits use, sharing, adaptation, distribution and reproduction in any medium or format, as long as you give appropriate credit to the original author(s) and the source, provide a link to the Creative Commons licence, and indicate if changes were made. The images or other third party material in this article are included in the article's Creative Commons licence, unless indicated otherwise in a credit line to the material. If material is not included in the article's Creative Commons licence and your intended use is not permitted by statutory regulation or exceeds the permitted use, you will need to obtain permission directly from the copyright holder. To view a copy of this licence, visit http://creativecommons.org/licenses/by/4.0/ The Creative Commons Public Domain Dedication waiver (http://creativecommons.org/publicdomain/zero/1.0/) applies to the data made available in this article, unless otherwise stated in a credit line to the data. 


\section{Case presentation}

A 64-year-old man presented to our hospital with abdominal pain. Computed tomography (CT) scan to investigate the cause of abdominal pain incidentally revealed multiple lung nodules. He had no history of malignant tumors. Thoracoabdominal CT revealed a solid tumor in the middle lobe of the right lung measuring $30 \mathrm{~mm}$ in diameter (Fig. 1A) and multiple bilateral lung nodules less than $5 \mathrm{~mm}$ in size (Fig. 1B). Primary lung cancer or multiple lung metastases from a malignant tumor originating in another organ was suspected. Because the lesions were difficult to access via a transbronchial approach, core needle biopsy of the tumor in the middle lobe of the right lung was performed via thoracoscopy. Histopathological examination revealed atypical cells with intranuclear cytoplasmic inclusions that formed papillary structures (Fig. 2A). In addition, immunohistochemical examination showed positive staining for thyroglobulin ( $\mathrm{Tg}$ ), thyroid transcription factor-1 (TTF-1), and PAX8, but negative staining for Napsin A (Fig. 2B-E). Based on these findings, the tumor was diagnosed as a metastasis of PTC.

Subsequently, the patient was closely examined for a primary lesion in the thyroid gland. Physical examination showed no palpable nodule on the neck. Although $\mathrm{Tg}$ antibody was positive, the serum $\mathrm{Tg}$ level was not elevated. Thyroid peroxidase antibody was negative [2.1 IU/
$\mathrm{mL}(\leq 5.2)]$. (Table 1). Ultrasonography revealed a hypoechoic nodule with an indistinct border measuring $0.9 \times$ $0.5 \mathrm{~cm}$ in the right lobe of the thyroid gland (Fig. 1C). Multiple lung nodules showed strong uptake on ${ }^{18} \mathrm{~F}$-fluorodeoxyglucose positron emission tomography (FDGPET), but no uptake was detected in the thyroid gland tumor (Fig. 1D). As fine needle aspiration cytology from the thyroid nodule demonstrated atypical cells with intranuclear cytoplasmic inclusions and grooved nuclei, the nodule was diagnosed as PTC. Consequently, the patient was diagnosed with PTMC with multiple lung metastases and underwent total thyroidectomy with central neck lymph node dissection.

Histopathological examination of the resected specimen revealed that the thyroid tumor in the right lobe was PTC $0.7 \times 0.3 \mathrm{~cm}$ in size (pT1a) with metastases to the paratracheal lymph nodes (pN1a). Histopathological findings of the tumor in the right lobe and metastatic lymph nodes were consistent with those observed in the lung tumor (Fig. 2F). Extrathyroid extension to the perithyroid soft tissue was detected (pEx1). Extranodal extension of the metastatic lymph nodes was not detected. The histopathological stage was Stage IVB [10]. Three months after the operation, the patient received radioactive iodine (RAI) therapy after withdrawal of thyroid hormone therapy for three weeks. A total of $3700 \mathrm{MBq}$ $(100 \mathrm{mCi})$ of RAI was administered for the initial
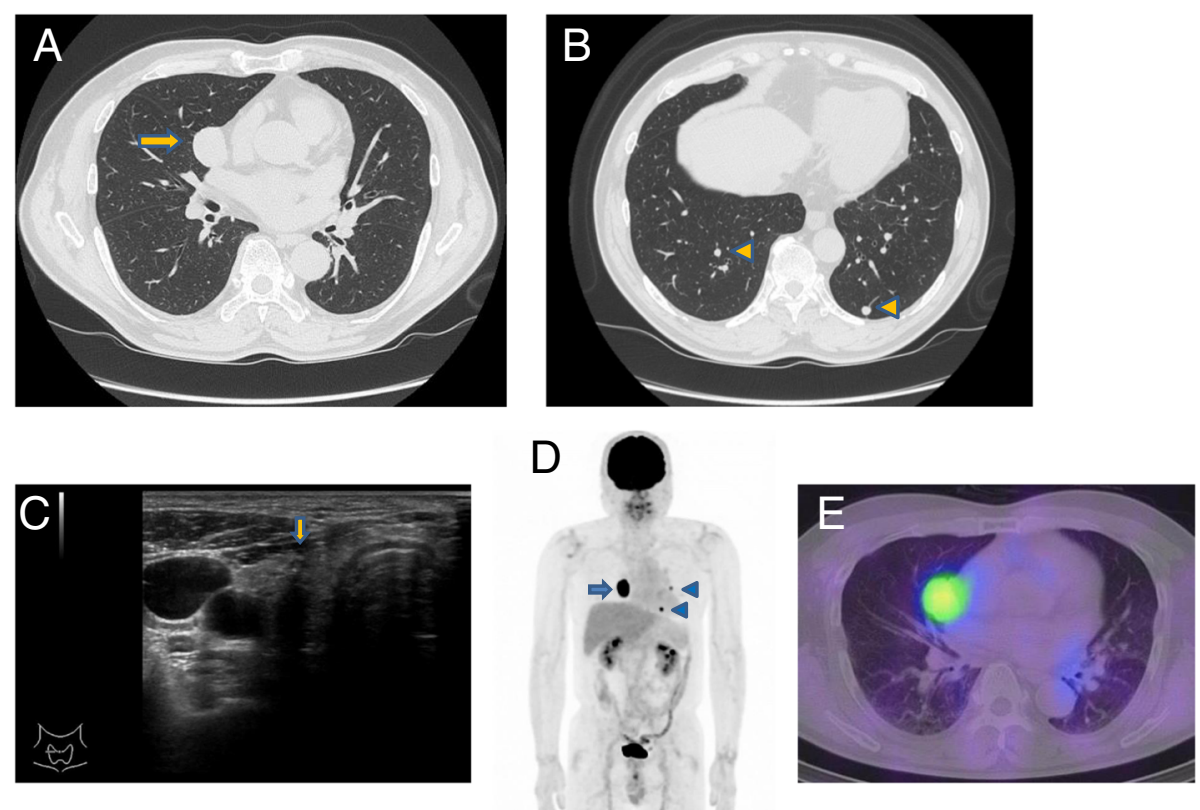

Fig. 1 A, B: Computed tomography findings in the lung. A solid $30 \mathrm{~mm}$ mass (arrow) in the middle lobe of the right lung (A) and several $5 \mathrm{~mm}$ nodules (arrowheads) (B) can be seen in both lungs. C: Ultrasonographic findings in the thyroid gland. A hypoechoic mass measuring $8.6 \times 4.6$ $\mathrm{mm}$ and showing an indistinct border can be seen in the right lobe of the thyroid gland (arrow). D: ${ }^{18} \mathrm{~F}$-fluorodeoxyglucose positron emission tomography (FDG-PET) findings. Strong FDG uptake is detected in the right lung tumor (arrow) and multiple tumors in the left lung (arrowhead). E: 131-iodine scintigraphy findings after the second radioactive iodine (RAI) treatment. 131-iodine has accumulated in the metastatic tumor in the middle lobe of the right lung 

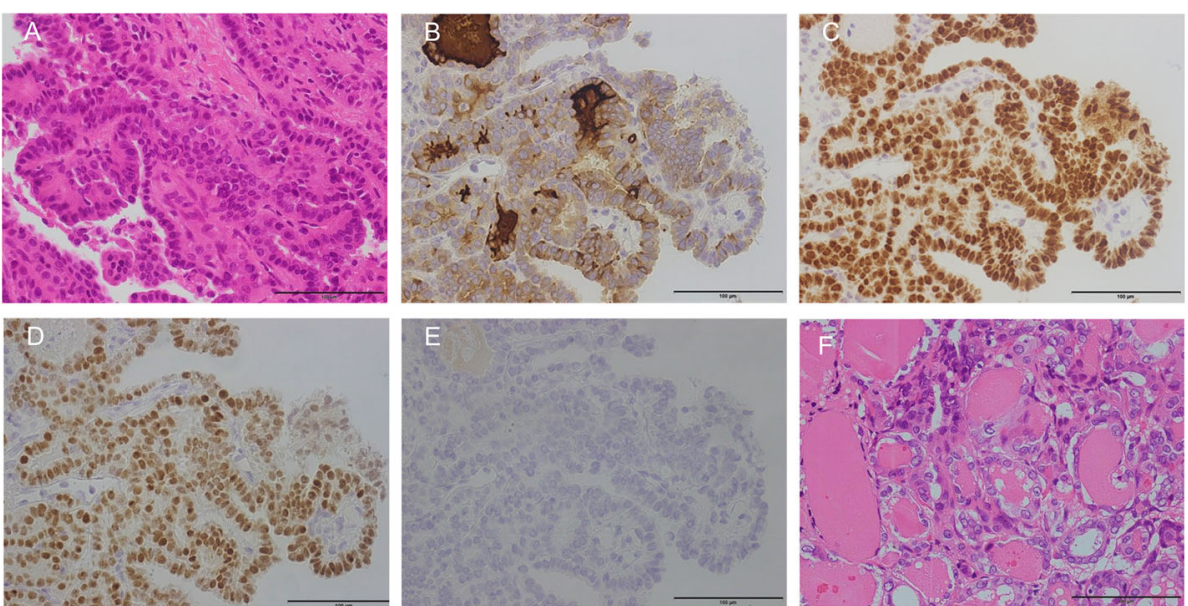

Fig. 2 A-E: Histopathological findings of the tumor in the middle lobe of the right lung. Atypical cells with intranuclear cytoplasmic inclusions have grown with papillary formations $(\mathbf{A} ; \mathrm{HE}, \times 100)$. The tumor cells are positive for thyroglobulin $(\mathbf{B} ; \times 100)$, thyroid transcription factor-1 $(\mathbf{C} ; \times$ 100), and PAX8 $(\mathbf{D} ; \times 100)$ and negative for Napsin $\mathbf{A}(\mathbf{E} ; \times 100)$. Scale bar: $100 \mu \mathrm{m}$. $\mathbf{F}$ : Histopathological findings of the thyroid. The tumor in the right lobe of the thyroid is diagnosed as papillary thyroid cancer, consistent with the lung tumor. Firm infiltration into the surrounding fat tissue can be observed (×100). Scale bar: $100 \mu \mathrm{m}$

therapy, and then 131-I scintigraphy was performed eight days later. In 131-I scintigraphy following the first RAI therapy, an accumulation of 131-I was observed in the thyroid bed alone. However, in the 131-I scintigraphy following the second and third therapies a strong 131-I accumulation was observed in the metastatic lesion in the right lung with the same amount of RAI (Fig. 1E). The patient's serum Tg level under TSH suppression did not change considerably when compared with that before the RAI treatment (Table 2). He has been well with no signs of progression in the lung and other organs 25 months after the operation.

\section{Discussion and conclusions}

The overall incidence of PTC continues to increase worldwide [11-14]. In addition, PTMC has increased due to the spread of health screening, technological progress in ultrasonography, and improved accuracy of ultrasonographyguided fine needle aspiration cytology [15-17]. Although PTCs generally grow slowly, lymph node metastases are

Table 1 Pre-operative blood test findings of the 64-year-old man with papillary thyroid microcarcinoma and lung metastases

\begin{tabular}{lll}
\hline Parameter & Normal range & Before surgery \\
\hline Free T3 $(\mathrm{pg} / \mathrm{ml})$ & $2.30-4.00$ & 3.10 \\
Free T4 $(\mathrm{pg} / \mathrm{ml})$ & $0.9-1.7$ & 1.36 \\
$\mathrm{TSH}(\mu \mathrm{IU} / \mathrm{ml})$ & $0.50-5.00$ & 2.27 \\
$\mathrm{Tg}(\mathrm{ng} / \mathrm{ml})$ & $\leq 33.7$ & 31.0 \\
$\mathrm{Tg} \mathrm{Ab}(\mathrm{IU} / \mathrm{ml})$ & $\leq 40.6$ & 53.9 \\
$\mathrm{TPO}$ Ab $(\mathrm{IU} / \mathrm{ml})$ & $\leq 5.2$ & 2.1 \\
\hline
\end{tabular}

$T S H$ thyroid stimulating hormone, $T g A b$ thyroglobulin antibody, TPO $A b$ thyroid peroxidase antibody, $\mathrm{Tg}$ thyroglobulin known to occur even when the primary tumor is small. As for PTMC, Elliot et al. reported that $11.5 \%$ of PTMC had cervical lymph node metastases in a retrospective study of 112 resected cases [18]. However, two prospective observational studies from Japan have reported that the incidence of distant metastasis from PTMC was very rare [3, 4]. Ito et al. reported that no patients developed distant metastasis for ten years after the diagnosis of PTMC in a study of 1235 patients observed without surgery [3]. Similarly, Sugitani et al. reported that no distant metastasis occurred in 230 non-surgical PTMC patients who were observed for ten years [4].

However, in a large-scale retrospective analysis using the Surveillance, Epidemiology and End Results (SEER) Cancer Database $(18,445$ cases) in the United States, $\mathrm{Yu}$ et al. reported that the incidence of distant metastasis from PTMC was 0.5\% [19]. In a recent retrospective analysis of 8808 patients with PTMC in Korea, Jeon et al. reported that 12 patients $(0.1 \%)$ had distant metastases, and four patients died of the primary disease [20]. Thus, although distant metastases from PTMC rarely

Table 2 Postoperative blood test findings of the 64-year-old man with papillary thyroid microcarcinoma and lung metastases

\begin{tabular}{rllll}
\hline Parameter & $\begin{array}{l}\text { Normal } \\
\text { range }\end{array}$ & $\begin{array}{l}\mathbf{3} \mathbf{M} \text { after } \mathbf{1 s t} \\
\text { RAl } \\
\text { treatment }\end{array}$ & $\begin{array}{l}\mathbf{3} \mathbf{M} \text { after } 2 \text { nd } \\
\text { RAI } \\
\text { treatment }\end{array}$ & $\begin{array}{l}\mathbf{3} \mathbf{M} \text { after } 3 \mathbf{r d} \\
\text { RAI } \\
\text { treatment }\end{array}$ \\
\hline $\mathrm{TSH}(\mu \mathrm{IU} / \mathrm{ml})$ & $\begin{array}{l}0.50- \\
5.00\end{array}$ & 0.005 & 0.007 & 0.005 \\
$\mathrm{Tg}(\mathrm{ng} / \mathrm{ml})$ & $\leq 33.7$ & 17.3 & 22.6 & 24.6 \\
$\mathrm{Tg} \mathrm{Ab}(\mathrm{IU} / \mathrm{ml})$ & $\leq 40.6$ & 21.5 & 12.9 & 14.4 \\
\hline
\end{tabular}

$M$ months, $T S H$ thyroid stimulating hormone, $T g A b$ thyroglobulin antibody, $T g$ thyroglobulin,

$R A /$ radioactive iodine 
Table 3 Clinicopathological features of previously reported cases of papillary thyroid microcarcinoma with distant metastasis

\begin{tabular}{|c|c|c|c|c|c|c|c|c|c|c|c|}
\hline No & $\begin{array}{l}\text { Author } \\
\text { Year }\end{array}$ & $\begin{array}{l}\text { Age } \\
\text { (years) } \\
\text { Sex }\end{array}$ & $\begin{array}{l}\text { Reasons } \\
\text { for } \\
\text { detection }\end{array}$ & $\begin{array}{l}\text { Diagnostic method } \\
\text { for PTMC } \\
\text { metastases }\end{array}$ & $\begin{array}{l}\text { Surgery for } \\
\text { thyroid }\end{array}$ & $\begin{array}{l}\text { Tumor } \\
\text { size } \\
(\mathrm{cm})\end{array}$ & $\mathrm{pN}$ & Ex & Metastatic site & $\begin{array}{l}131-I \\
\text { therapy }\end{array}$ & Prognosis \\
\hline 1 & $\begin{array}{l}\text { Murakami, } \\
\text { et al. , } 2001 \\
\text { [5] }\end{array}$ & $\begin{array}{l}63 \\
M\end{array}$ & $\begin{array}{l}\text { Abdominal } \\
\text { tumor }\end{array}$ & $\begin{array}{l}\text { Extirpation of } \\
\text { abdominal tumor }\end{array}$ & $\begin{array}{l}\text { Partial resection of } \\
L \text { thyroid lobe and } \\
N D\end{array}$ & 0.1 & + & $\begin{array}{l}\mathrm{N} . \\
\mathrm{A}\end{array}$ & Rectus muscle & - & $\begin{array}{l}1 \text { y } 8 \mathrm{~m}, \\
\text { alive }\end{array}$ \\
\hline 2 & $\begin{array}{l}\text { Yamada, } \\
\text { et al., } 2001 \\
{[14]}\end{array}$ & $\begin{array}{l}68 \\
M\end{array}$ & Chest $\mathrm{X}$ ray & $\begin{array}{l}\text { Fiberoptic } \\
\text { bronchoscopic } \\
\text { biopsy }\end{array}$ & $\Pi$ & $<1.0$ & $\begin{array}{l}\mathrm{N} . \\
\mathrm{A}\end{array}$ & $\begin{array}{l}\mathrm{N} . \\
\mathrm{A}\end{array}$ & Lung & + & $\begin{array}{l}1 \text { y } 10 \mathrm{~m} \text {, } \\
\text { alive }\end{array}$ \\
\hline 3 & $\begin{array}{l}\text { Erdem, } \\
\text { et al., } 2003 \\
\text { [20] }\end{array}$ & $\begin{array}{l}40 \\
M\end{array}$ & Dysphagia & $\begin{array}{l}\text { Resection of a } \\
\mathrm{R} \text { parapharyngeal } \\
\text { mass }\end{array}$ & $\Pi$ and ND & 0.8 & - & $\begin{array}{l}\mathrm{N} \\
\mathrm{A}\end{array}$ & Parapharyngeal & + & $3 y$, alive \\
\hline 4 & $\begin{array}{l}\text { Liou, et al., } \\
2005 \text { [21] }\end{array}$ & $50 \mathrm{~F}$ & $\begin{array}{l}\text { Right pelvic } \\
\text { fracture }\end{array}$ & $\begin{array}{l}\mathrm{R} \text { hemipelvectomy } \\
\text { and renal biopsy }\end{array}$ & $\pi$ & 1 & $\begin{array}{l}\mathrm{N} . \\
\mathrm{A}\end{array}$ & $\mathrm{N}$. & $\begin{array}{l}\text { Kidney, pelvic bone, } \\
\text { lung }\end{array}$ & + & $\begin{array}{l}\text { about } 3 \mathrm{y} \text {, } \\
\text { alive }\end{array}$ \\
\hline 5 & $\begin{array}{l}\text { Itoh, et al. } \\
2008 \text { [22] }\end{array}$ & $82 \mathrm{~F}$ & $\begin{array}{l}\text { Cough, } \\
\text { back pain }\end{array}$ & $\begin{array}{l}\text { Fiberoptic } \\
\text { bronchoscopic } \\
\text { biopsy }\end{array}$ & None & 0.6 & $\begin{array}{l}\mathrm{N} . \\
\mathrm{A}\end{array}$ & + & $\begin{array}{l}\text { Brain, liver, pancreas, } \\
\text { kidney, ovary, bone, } \\
\text { lung }\end{array}$ & - & $7 \mathrm{~m}$, dead \\
\hline 6 & $\begin{array}{l}\text { Lecumberri, } \\
\text { et al., } 2010 \\
\text { [23] }\end{array}$ & $65 \mathrm{~F}$ & $\begin{array}{l}\text { Headache, } \\
\text { tinnitus }\end{array}$ & $\begin{array}{l}\text { Resection of a } \\
\text { cerebellar mass }\end{array}$ & $\Pi$ and ND & 0.2 & - & + & Brain & + & $7 y$, dead \\
\hline 7 & $\begin{array}{l}\text { Xu, et al. } \\
2011 \text { [24] }\end{array}$ & $46 \mathrm{~F}$ & $\begin{array}{l}\text { Cervical } \\
\text { mass }\end{array}$ & $\begin{array}{l}\text { 131-I WBS and SPEC } \\
\text { T/CT }\end{array}$ & $\Pi \pi$ and ND & 0.3 & + & $\begin{array}{l}\mathrm{N} \\
\mathrm{A}\end{array}$ & Brain, lung & + & $3 \mathrm{~m}$, alive \\
\hline 8 & $\begin{array}{l}\text { Saito, et al., } \\
2011 \text { [25] }\end{array}$ & $70 \mathrm{~F}$ & Cough & R lung lobectomy & $\begin{array}{l}\text { Subtotal } \\
\text { thyroidectomy and } \\
\text { ND }\end{array}$ & 0.8 & - & $\begin{array}{l}\mathrm{N} \\
\mathrm{A}\end{array}$ & Lung & - & $\begin{array}{l}3 \text { y } 10 \mathrm{~m} \text {, } \\
\text { alive }\end{array}$ \\
\hline 9 & $\begin{array}{l}\text { Kozu, et al. } \\
2014 \text { [26] }\end{array}$ & $\begin{array}{l}70 \\
M\end{array}$ & Chest $C T$ & L lung lobectomy & None & N. A & $\begin{array}{l}\mathrm{N} . \\
\mathrm{A}\end{array}$ & N. & Lung & - & $4 \mathrm{~m}$, alive \\
\hline 10 & $\begin{array}{l}\text { Kaseda, } \\
\text { et al., } 2016 \\
{[27]}\end{array}$ & $66 \mathrm{~F}$ & Chest $\subset T$ & $\begin{array}{l}\text { Transbronchial } \\
\text { biopsy and R lung } \\
\text { lobectomy }\end{array}$ & None & N. A & $\begin{array}{l}\mathrm{N} . \\
\mathrm{A}\end{array}$ & $\begin{array}{l}\mathrm{N} \\
\mathrm{A}\end{array}$ & Lung & - & N. A \\
\hline 11 & $\begin{array}{l}\text { Kawai, et al., } \\
2016[28]\end{array}$ & $\begin{array}{l}\ln 70^{\prime} s \\
M\end{array}$ & $\begin{array}{l}\text { Chest } \\
\text { discomfort }\end{array}$ & R lung lobectomy & $\begin{array}{l}\text { R thyroid } \\
\text { lobectomy } \\
\text { and ND }\end{array}$ & 1 & + & + & Lung & - & $11 \mathrm{y}$, alive \\
\hline 12 & $\begin{array}{l}\text { Jeon, et al., } \\
2016 \text { [19] }\end{array}$ & $51 \mathrm{~F}$ & Neck US & $\begin{array}{l}\text { 131-I WBS and SPEC } \\
\text { T/CT }\end{array}$ & $\Pi$ and ND & 0.8 & + & - & Lung & + & $1.9 y$, alive \\
\hline 13 & $\begin{array}{l}\text { Jeon, et al., } \\
2016 \text { [19] }\end{array}$ & $31 \mathrm{~F}$ & Neck US & $\begin{array}{l}\text { 131-I WBS and SPEC } \\
\text { T/CT }\end{array}$ & $\Pi$ and ND & 0.9 & + & + & Lung, bone & + & $6.7 \mathrm{y}$, alive \\
\hline 14 & $\begin{array}{l}\text { Jeon, et al., } \\
2016 \text { [19] }\end{array}$ & $55 \mathrm{~F}$ & Neck US & $\begin{array}{l}\text { 131-I WBS and SPEC } \\
\text { T/CT }\end{array}$ & $\Pi \mathrm{T}$ and ND & 0.9 & + & + & Lung, bone & + & $7.6 \mathrm{y}$, alive \\
\hline 15 & $\begin{array}{l}\text { Jeon, et al., } \\
2016 \text { [19] }\end{array}$ & $59 \mathrm{~F}$ & Neck US & $\begin{array}{l}\text { 131-I WBS and SPEC } \\
\text { T/CT }\end{array}$ & $\Pi$ and ND & 1 & + & + & Lung & + & $2.1 \mathrm{y}$, alive \\
\hline 16 & $\begin{array}{l}\text { Jeon, et al., } \\
2016 \text { [19] }\end{array}$ & $73 \mathrm{~F}$ & Neck US & $\begin{array}{l}\text { 131-I WBS and SPEC } \\
\text { T/CT }\end{array}$ & $\Pi$ and ND & 1 & + & + & Lung & + & $8.8 \mathrm{y}$, alive \\
\hline 17 & $\begin{array}{l}\text { Jeon, et al., } \\
2016 \text { [19] }\end{array}$ & $54 \mathrm{~F}$ & Hoarseness & $\begin{array}{l}\text { 131-I WBS and SPEC } \\
\text { T/CT }\end{array}$ & $\Pi$ and ND & 0.8 & + & + & Lung & + & $\begin{array}{l}10.7 y, \\
\text { alive }\end{array}$ \\
\hline 18 & $\begin{array}{l}\text { Jeon, et al., } \\
2016 \text { [19] }\end{array}$ & $63 \mathrm{~F}$ & Neck mass & $\begin{array}{l}\text { 131-I WBS and SPEC } \\
\text { T/CT }\end{array}$ & $\Pi$ and ND & 0.8 & + & + & Lung & + & $\begin{array}{l}11.4 y_{1} \\
\text { dead }\end{array}$ \\
\hline 19 & $\begin{array}{l}\text { Jeon, et al., } \\
2016 \text { [19] }\end{array}$ & $46 \mathrm{~F}$ & Chest $C T$ & $\begin{array}{l}\text { 131-I WBS and SPEC } \\
\text { T/CT }\end{array}$ & $\Pi$ and ND & 0.7 & + & + & Lung, bone & + & $15 \mathrm{y}$, alive \\
\hline 20 & $\begin{array}{l}\text { Jeon, et al., } \\
2016 \text { [19] }\end{array}$ & $\begin{array}{l}65 \\
M\end{array}$ & Hoarseness & $\begin{array}{l}\text { 131-I WBS and SPEC } \\
\text { T/CT }\end{array}$ & $\Pi \mathrm{a}$ and ND & 0.6 & + & - & Lung, bone & + & $1 \mathrm{y}$, dead \\
\hline 21 & $\begin{array}{l}\text { Jeon, et al., } \\
2016 \text { [19] }\end{array}$ & $\begin{array}{l}58 \\
M\end{array}$ & Neck mass & $\begin{array}{l}131-I \text { WBS and SPEC } \\
\text { T/CT }\end{array}$ & $\Pi$ and ND & 1 & + & - & Lung, brain & + & $\begin{array}{l}4.9 y \\
\text { dead }\end{array}$ \\
\hline 22 & $\begin{array}{l}\text { Jeon, et al., } \\
2016 \text { [19] }\end{array}$ & $60 \mathrm{~F}$ & Neck mass & $\begin{array}{l}\text { 131-I WBS and SPEC } \\
\text { T/CT }\end{array}$ & $\Pi$ and ND & 0.8 & + & - & Lung, brain & + & $10 \mathrm{y}$, dead \\
\hline
\end{tabular}


Table 3 Clinicopathological features of previously reported cases of papillary thyroid microcarcinoma with distant metastasis (Continued)

\begin{tabular}{|c|c|c|c|c|c|c|c|c|c|c|c|}
\hline No & $\begin{array}{l}\text { Author } \\
\text { Year }\end{array}$ & $\begin{array}{l}\text { Age } \\
\text { (years) } \\
\text { Sex }\end{array}$ & $\begin{array}{l}\text { Reasons } \\
\text { for } \\
\text { detection }\end{array}$ & $\begin{array}{l}\text { Diagnostic method } \\
\text { for PTMC } \\
\text { metastases }\end{array}$ & $\begin{array}{l}\text { Surgery for } \\
\text { thyroid }\end{array}$ & $\begin{array}{l}\text { Tumor } \\
\text { size } \\
(\mathrm{cm})\end{array}$ & $\mathrm{pN}$ & Ex & Metastatic site & $\begin{array}{l}131-I \\
\text { therapy }\end{array}$ & Prognosis \\
\hline 23 & $\begin{array}{l}\text { Jeon, et al., } \\
2016 \text { [19] }\end{array}$ & $63 \mathrm{~F}$ & Neck mass & $\begin{array}{l}\text { 131-I WBS and SPEC } \\
\text { T/CT }\end{array}$ & $\Pi \mathrm{T}$ and $\mathrm{ND}$ & 0.9 & + & + & Lung, bone & + & $\begin{array}{l}10.7 y \\
\text { dead }\end{array}$ \\
\hline 24 & Our case & $\begin{array}{l}64 \\
M\end{array}$ & Chest CT & $\begin{array}{l}\text { Lung biopsy via } \\
\text { VATS }\end{array}$ & $\Pi T$ and ND & 0.7 & + & + & Lung & + & $\begin{array}{l}2 \text { y } 1 \mathrm{~m}, \\
\text { alive }\end{array}$ \\
\hline
\end{tabular}

$p N$ pathological cervical lymph node metastases, Ex extrathyroid extension, 131-I 131-iodine, WBS whole body scan,

SPECT/CT single-photon emission computed tomography, CT computed tomography, VATS video-assisted thoracic surgery, $T T$ total thyroidectomy, ND neck dissection, N.A not available, $y$ years, $m$ months

occur, PTMC should be included in the differential diagnosis list for the primary lesion when metastatic lesions from unknown origins are encountered.

To identify risk factors for distant metastases from PTMC, we searched the literature for cases of distant metastasis from PTMC, which were confirmed by histological examination or RAI uptake over the past 20 years and found 24 such cases (Table 3) [5, 15, 20-29]. In the analysis of the SEER cancer database reported by $\mathrm{Yu}$ et al. [19], there were 91 cases of distant metastases from PTMC; however, detailed clinical information of each patient was not reported. Therefore, we excluded these cases from our present analysis. It has been generally considered that tumor size, extraglandular extension of the primary tumor, extranodal extension of metastatic lymph nodes, size of metastatic lymph nodes, older age, and male sex are possible risk factors for recurrence of PTC [30-33]. In addition, the recently revised TNM staging system defined a high risk for people who were $\geq$ 55 years of age [10]. Jeon et al. recently reported the association of disease-specific mortality with old age, large metastatic lymph nodes with extranodal extension, and a change to an aggressive pathologic subtype of metastatic lymph nodes by analyzing a large number of patients with PTMC [20]. Although detailed information on pathological diagnosis was not stated for several of the 24 cases found in the literature, either lymph node metastasis or extraglandular extension was observed in most patients, including the present case, and the average age of these cases was $58.8 \pm 12.0$ years. Thus, the possibility of distant metastases should be considered in PTMC cases with risk factors for PTC recurrence.

Recently, Song et al. identified Mesenteric Estrogen Dependent Adipogenesis (MEDAG) as one of the genes associated with lymph node metastases and poor disease-free survival of patients with PTMC by analyzing the microarray data from The Cancer Genome Atlas [34]. Although the significance of MEDAG in the onset of distant metastasis has not been elucidated, it is expected that predictive factors of distant metastasis will be identified by multigene analyses of a large number of cases in the near future.
RAI therapy is the standard therapy for distant metastases from PTC, and patients must undergo total thyroid gland resection before treatment. However, it is known that completion thyroidectomy is associated with a higher incidence of surgical complications, such as recurrent laryngeal nerve paralysis and permanent hypoparathyroidism, compared with initial surgery [35]. To avoid such complications due to re-operation, PTC patients should be carefully assessed for distant metastases by CT or other imaging modalities before surgery, and if there are distant metastases, total thyroidectomy should be performed in the first surgery.

However, Kawano et al. recently showed that routine chest $\mathrm{CT}$ at the time of PTMC diagnosis did not identify distant lung metastasis in 1000 patients with low-risk PTMC and suggested that chest CT is not beneficial for patients with PTMC in relation to factors such as cost, radiation exposure [36]. Considering these findings, when cervical ultrasonography reveals the existence of extrathyroidal extension of the primary lesion, extranodal extension of the metastatic lymph nodes, or large metastatic lymph nodes in patients over 55 years of age, we should consider screening for distant metastases to avoid complications from reoperation and to facilitate subsequent RAI therapy.

In conclusion, PTMC with multiple lung metastases is rare. Although active surveillance of PTMC is expected to remain the standard for care, this case suggests that a subset of PTMC patients may develop distant metastases. In particular, screening for distant metastases should be considered in patients with risk factors for recurrence of PTC.

\footnotetext{
Abbreviations

PTC: papillary thyroid carcinoma; PTMC: papillary thyroid microcarcinoma; 131-I: lodine-131; CT: Computed tomography; Tg: Thyroglobulin; TTF-

1: Thyroid transcription factor-1; FDG-PET: ${ }^{18}$ F-fluorodeoxyglucose positron emission tomography; Tg Ab: Thyroglobulin antibody; TSH: Thyroid stimulating hormone; TPO Ab: Thyroid peroxidase antibody; RAl: Radioactive iodine; SEER: Surveillance, Epidemiology and End Results; MEDAG: Mesenteric Estrogen Dependent Adipogenesis
}

Acknowledgements

We are grateful to Editage for proofreading. 


\section{Authors' contributions}

$\mathrm{TS}, \mathrm{TO}$, and $\mathrm{KI}$ wrote the manuscript. TC, AS, MO, TI, TK, and KM revised the manuscript. YS and TU evaluated the pathological findings. All authors read and approved the final manuscript.

\section{Funding}

The authors did not receive any funding for this study.

\section{Availability of data and materials}

The datasets used during the current study are available from the corresponding author on reasonable request.

\section{Declarations}

\section{Ethics approval and consent to participate}

Written informed consent was obtained from the patient for participation in this study.

\section{Consent for publication}

Written informed consent was obtained from the patient for publication of this case report and any accompanying images.

\section{Competing interests}

The authors declare that they have no competing interests.

\section{Author details}

'Division of Breast and Endocrine Surgery, Department of Surgery, Shinshu University School of Medicine, 3-1-1 Asahi, Matsumoto, Nagano 390-8621, Japan. 'Division of Laboratory Medicine, Shinshu University Hospital,

Matsumoto, Japan.

\section{Received: 3 April 2021 Accepted: 1 June 2021}

Published online: 11 June 2021

\section{References}

1. Ito Y, Uruno T, Nakano K, Takamura Y, Miya A, Kobayashi K, et al. An observation trial without surgical treatment in patients with papillary microcarcinoma of the thyroid. Thyroid. 2003;13(4):381-7. https://doi.org/1 $0.1089 / 105072503321669875$.

2. Ito $Y$, Miyauchi A, Inoue H, Fukushima M, Kihara M, Higashiyama T, et al. An observational trial for papillary thyroid microcarcinoma in Japanese patients. World J Surg. 2010;34(1):28-35. https://doi.org/10.1007/s00268-009-0303-0.

3. Ito Y, Miyauchi A, Kihara M, Higashiyama T, Kobayashi K, Miya A. Patient age is significantly related to the progression of papillary microcarcinoma of the thyroid under observation. Thyroid. 2014;24(1):27-34. https://doi.org/10.1 089/thy.2013.0367.

4. Sugitani I, Toda K, Yamada K, Yamamoto N, Ikenaga M, Fujimoto Y. Three distinctly different kinds of papillary thyroid microcarcinoma should be recognized: our treatment strategies and outcomes. World J Surg. 2010; 34(6):1222-31. https://doi.org/10.1007/s00268-009-0359-x.

5. Murakami S, Hiraguchi E, Satoh M, Maeda Y, Kondo S, et al. A case of minute carcinoma of the thyroid thought to be the primary tumor of the metastatic tumors to the anterior cervical muscle and the rectus muscle. J Japan Surg Assoc. 2001;62(11):2631-5. (In Japanese). https://doi.org/10.3919/ jijsa.62.2631.

6. Kim KE, Kim EK, Yoon JH, Han KH, Moon HJ, Kwak JY. Preoperative prediction of central lymph node metastasis in thyroid papillary microcarcinoma using clinicopathologic and sonographic features. World J Surg. 2013:37(2):385-91. https://doi.org/10.1007/s00268-012-1826-3.

7. Mercante G, Frasoldati A, Pedroni C, Formisano D, Renna L, Piana S, et al. Prognostic factors affecting neck lymph node recurrence and distant metastasis in papillary microcarcinoma of the thyroid: results of a study in 445 patients. Thyroid. 2009;19(7):707-16. https://doi.org/10.1089/thy.2008.02 70.

8. Noguchi S, Yamashita H, Uchino S, Watanabe S. Papillary microcarcinoma. World J Surg. 2008;32(5):747-53. https://doi.org/10.1007/s00268-007-9453-0.

9. Pazaitou PK, Capezzone M, Pacini F. Clinical features and therapeutic implication of papillary thyroid microcarcinoma. Thyroid. 2007:17(11):108592. https://doi.org/10.1089/thy.2007.0005.

10. UICC. TNM classification of malignant Tumours. 8th ed. James DB, Mary KG, Christian W, editors. Wiley-Blackwell: In; 2016.
11. Salamanca-Fernández E, Rodriguez-Barranco M, Chang-Chan $\mathrm{YL}$, RedondoSánchez D, Domínguez-López S, Bayo E, et al. Thyroid Cancer epidemiology in South Spain: a population-based time trend study. Endocrine. 2018;62(2): 423-31. https://doi.org/10.1007/s12020-018-1681-6.

12. Du L, Wang Y, Sun $X$, Li H, Geng X, Ge M, et al. Thyroid cancer: trends in incidence, mortality and clinical-pathological patterns in Zhejiang Province, Southeast China. BMC Cancer. 2018;18(1):291. https://doi.org/10.1186/s12 885-018-4081-7.

13. Davies L, Welch HG. Increasing incidence of thyroid cancer in the United States, 1973-2002. JAMA. 2006;295(18):2164-7. https://doi.org/10.1001/jama.2 95.18.2164.

14. Deng Y, Li H, Wang M, Li N, Tian T, Wu Y, et al. Global burden of thyroid Cancer from 1990 to 2017. JAMA Netw Open. 2020;3(6):e208759. https://doi. org/10.1001/jamanetworkopen.2020.8759.

15. Yamada $H$, Fujita $K$, Ishida R. Diagnosis and treatment of small thyroid cancer. Jpn J Cancer Clin. 2001;47:421-8 (In Japanese).

16. Shulin JH, Aizhen J, Kuo SM, Tan WB, Ngiam KY, Parameswaran R. Rising incidence of thyroid cancer in Singapore not solely due to micropapillary subtype. Ann R Coll Surg Engl. 2018;100(4):295-300. https://doi.org/10.1308/ rcsann.2018.0004

17. Hakala T, Kellokumpu LP, Kholová I, Holli K, Huhtala H, Sand J. Rising incidence of small size papillary thyroid cancers with no change in disease specific survival in Finnish thyroid cancer patients. Scand J Surg. 2012;101(4): 301-6. https://doi.org/10.1177/145749691210100415.

18. Elliott M, Gao K, Gupta R, Chua EL, Gargya A, Clark J. Management of incidental and non-incidental papillary thyroid microcarcinoma. J Larygol Otol. 2013;127(Suppl 2):S17-23. https://doi.org/10.1017/S0022215113000455.

19. Yu XM, Wan Y, Sippel RS, Chen H. Should all papillary thyroid microcarcinomas be aggressively treated? An analysis of 18,445 cases. Ann Surg. 2011;254(4):653-60. https://doi.org/10.1097/SLA.0b013e318230036d.

20. Jeon M, Kim WG, Choi YM, Kwon H, Lee YM, Sung TY, et al. Features predictive of distant metastasis in papillary thyroid microcarcinomas. Thyroid. 2016;26(1):161-8. https://doi.org/10.1089/thy.2015.0375.

21. Erdem T, Miman MC, Oncel S, Mizrak B. Metastatic spread of occult papillary carcinoma of the thyroid to the parapharyngeal space: a case report. Kulak Burun Bogaz Ihtis Derg. 2003;10(6):244-7.

22. Liou MJ, Lin JD, Chung MH, Liau CT, Hsueh C. Renal metastasis from papillary thyroid microcarcinoma. Acta Otolaryngol. 2005;125(4):438-42. https://doi.org/10.1080/00016480410022822.

23. Itoh M, Oh-ishi S, Senba S, Nemoto K, Hatao H, Shimizudani N, et al. A case of occult thyroid cancer detected as a solitary nodular lung metastasis. Nihon Kokyuki Gakkai Zasshi. 2008;46(7):578-82. (In Japanese).

24. Lecumberri B, Alvarez EC, Martin VP, Nistal M, Martín V, Riesco-Eizaguirre G, et al. Solitary hemorrhagic cerebellar metastasis from occult papillary thyroid microcarcinoma. Thyroid. 2010;20(5):563-7. https://doi.org/10.1089/ thy.2010.0062

25. Xu YH, Song HJ, Qiu ZL, Luo QY. Brain metastases with exceptional features from papillary thyroid carcinoma: report of three cases. Hell J Nucl Med. 2011;14(1):56-9.

26. Saito G, Sakaizawa T, Yamada K, Arimura T, Nishimura H, et al. A case of minimal thyroid carcinoma diagnosed by a solitary pulmonary nodule. Journal of Shinshu medical association. 2011;59(2):89-95 (In Japanese).

27. Kozu Y, Futagawa T, Suzuki K. Pulmonary metastases from colon cancer and occult thyroid cancer in the same lobe. Kyobu Geka. 2014;67(6):448-51. (In Japanese).

28. Kaseda K, Watanabe K, Sakamaki H, Kazama A. Solitary pulmonary metastasis from occult papillary thyroid carcinoma. Thorac Cancer. 2016;7(2):261-3. https://doi.org/10.1111/1759-7714.12295.

29. Kawai $H$, Sugimoto $R$, Iga $N$, Ikeda $H$, Yoshida $R$, Waki N, et al. A case of minimal thyroid carcinoma diagnosed by a solitary pulmonary metastasis. Gan To Kagaku Ryoho. 2016:43(12):2127-9. (In Japanese).

30. Hay ID, Grant CS, Tayor WF, McConahey WM. Ipsilateral lobectomy versus bilateral lobar resection in papillary thyroid carcinoma: a retrospective analysis of surgical outcome using a novel prognostic scoring system. Surgery. 1987;102(6):1088-95

31. Hay ID, Bergstralh EJ, Goellner JR, Ebersold JR, Grant CS. Predicting outcome in papillary thyroid carcinoma: development of a reliable prognostic scoring system in a cohort of 1779 patients surgically treated at one institution during 1940 through 1989. Surgery. 1993;114:1050-8.

32. Sugitani I, Kasai N, Fujimoto Y, Yanagisawa A. A novel classification system for patients with PTC: addition of the new variables of large $(3 \mathrm{~cm}$ or 
greater) nodal metastases and reclassification during the follow-up period. Surgery. 2004;135(2):139-48. https://doi.org/10.1016/\$0039-6060(03)00384-2.

33. Noguchi S, Murakami N, Kawamoto H. Classification of papillary cancer of the thyroid based on prognosis. World J Surg. 1994;18:1050-8.

34. Song Y, Fu L, Li H, Qiu X. Evaluation of MEDAG gene expression in papillary thyroid microcarcinoma: associations with histological features, regional lymph node metastasis and prognosis. Sci Rep. 2019;9(1):5800. https://doi. org/10.1038/s41598-019-41701-4.

35. Ito Y, Kihara M, Kobayashi K, Miya A, Miyauchi A. Permanent hypoparathyroidism after completion total thyroidectomy as a second surgery: how do we avoid it? Endocr J. 2014;61(4):403-8. https://doi.org/10.1 507/endocrj.EJ13-0503

36. Kawano S, Miyauchi A, Ito Y. Routine chest computed tomography at presentation does not identify distant metastasis in cT1aNO papillary thyroid carcinoma. Thyroid. 2020:30(11):1620-4. https://doi.org/10.1089/thy.2020. 0073.

\section{Publisher's Note}

Springer Nature remains neutral with regard to jurisdictional claims in published maps and institutional affiliations.

Ready to submit your research? Choose BMC and benefit from:

- fast, convenient online submission

- thorough peer review by experienced researchers in your field

- rapid publication on acceptance

- support for research data, including large and complex data types

- gold Open Access which fosters wider collaboration and increased citations

- maximum visibility for your research: over $100 \mathrm{M}$ website views per year

At BMC, research is always in progress.

Learn more biomedcentral.com/submissions 